\title{
IASPM Hungary: Developments and new directions in popular music research
}

\author{
Emília Barna \\ Budapest University of Technology and Economics \\ ebarna@eik.bme.hu
}

\begin{abstract}
Amidst political and economic changes shaping both the field of popular music and popular music studies in Hungary, including changes in the financing and institutional framework of academic research, as well as a growing intensity in the state funding of popular music - which, at the same time, has contributed to the creation of a system of dependency on the state - the Hungarian branch, celebrating its tenth anniversary this year, has seen considerable activity in the last few years. This includes the organising of the first international popular music conferences in Hungary, as well as the joining of new, young scholar members, and the strengthening of new research areas. The most prominent areas are the history of popular music research in Hungary, popular music histories and historiography, jazz studies, studies of (digital) technology and popular music, research on the relationship between popular music and populism, and on popular music and gender.
\end{abstract}

\section{The changing context of popular music research in Hungary}

The Hungarian branch, which is celebrating its tenth anniversary this year, has seen considerable activity since the last country report from January 2016 (Barna 2016) and the publication of Made in Hungary: Studies in Popular Music (Barna and Tofalvy 2017); a volume that provided international readers with an overview of popular music research taking place at the time in Hungary, both inside and outside of the local branch, including the organising of the first international popular music conferences in Hungary as well as the joining of new, young scholar members. Thanks to these developments, the past few years have seen the emergence and strengthening of new research areas.

Both the field of popular music and popular music studies have been shaped by recent political and economic changes. Firstly, the past six years have seen a growing intensity in the state funding of popular music in Hungary. In 2014 a new popular music programme named Cseh Tamás (later renamed Hangfoglaló Programme), organised under the National Cultural Fund (NKA, chaired by the Minister of Human Resources), was introduced under the Fidesz government. The

IASPM Journal vol.10 no.1 (2020) 
programme includes: funding of writing, recording and video production for artists; funding for national and international tours (the latter under music export); the supporting of live music venues; as well as popular music education and heritage. The last of these involves popular music history scholarship. On the one hand, this is the first instance in which popular music has received significant state-level recognition and support since 1989. Nevertheless, this has also contributed to the creation of a strong system of dependency on the state, which is fragile due to being directly contingent upon political shifts. Moreover, it may also be critically viewed as part of a process of increasing ideological influence and control of the cultural sphere (Barna et al. 2019).

Popular music research is also affected by issues relating to financing and autonomy. The research network historically belonging to the Hungarian Academy of Sciences, including the Institute of Musicology, has been moved under a newly established research network. The Institute of Musicology plays a crucial part in the history of popular music studies in Hungary, starting with János Maróthy's foundation of a Music Sociology Department in 1971, which was also the academic home to long-time IASPM member Anna Szemere before her move to the United States. In recent times, the Institute has again come to assume an important role in popular music research which has included hosting the majority of popular music conferences taking place in the country, thanks to the work of our branch member Ádám Ignácz.

At the time of writing, in Hungary as elsewhere in the world, the COVID-19 pandemic has put a stop to all live music activity, endangering the livelihoods of thousands of workers in the music industries. On a hopeful note, the financing of music has perhaps never received the amount of public attention it is receiving now; nor the precarity of labour in the music (and cultural) industries. The work of wedding musicians, sound and light technicians, roadies, and photographers, usually remaining hidden in the background, has now, to an extent, been made visible by the crisis. Although an economic crisis seems inevitable, the fact that issues around cultural work and solidarity are being discussed may give rise to some optimism.

At the same time, the economic crisis in the wake of the pandemic is already threatening not only the live music industry but also such sectors as book publishing, as well as the financing of universities, which may, again, directly impact academic research in many places around the world. Therefore, in these times local and national-level organising and solidarity should be at the forefront of our thinking.

\section{Current directions in Hungarian popular music studies}

In the following, I attempt to summarise the most important emerging directions in Hungarian popular music studies. First of all, the history of popular music research in Hungary itself has been brought to the fore through, firstly, a conference organised by Ádám Ignácz in March 2019 at the aforementioned Institute of Musicology, entitled A magyar populáris zene története(i): Források - módszerek perspektívák ("The History/-ies of Hungarian Popular Music: Sources - Methods Perspectives"). This conference included a roundtable discussion on the history, as well as the present, of popular music studies in Hungary. Moreover, Ádám Ignácz' forthcoming monograph (2020a) provides an in-depth account of popular music research in state socialist Hungary: a history that has remained mostly hidden both 
inside and outside of Hungary (see also Barna and Ignácz 2018). With strong emphasis on the political and ideological context of culture and academic research under the state socialist regime, the monograph offers novel insight into the academic and public debates around the aesthetic, social, and political roles and function of popular music during the fifties and sixties, providing an account of the birth of local popular music research. Locally, the reasons behind the forgetting of this history in post-socialist times are tied to the close association of Marxist thought with state ideology, based on which the hegemonic post-socialist intellectual elite made a clear break with its theoretical legacy. However, on an international level, the forgetting of academic knowledge generated outside of the Western core despite the active participation of scholars such as János Maróthy on the international scene during the early years of IASPM - can also be regarded as a result of the global inequalities of knowledge production. This ensures the central position of Western knowledge production being asserted at the expense of knowledge production taking place at the global periphery and semi-periphery, including Eastern Europe, which underlines the significance of such endeavours as Ignácz's.

Returning to the aforementioned conference and a forthcoming Hungarianlanguage volume (Ignácz 2020b), their primary focus was popular music histories/historiography: another area that has seen the emergence of new research. One example is the work of Sára Wagner, who has researched and published on the historiography of the Hungarian progressive rock/jazz rock band Syrius, which spent part of its career in Australia in the early 1970s (Wagner 2018). Wagner's article, which is based on painstaking archival research, sheds light on the construction of an underground, and the relations between genre and cultural policy in socialist Hungary, while also exploring the ambivalent relation between official (state) and unofficial (DIY) archival practice. Another example is the work of Anna Szemere who, even though formally not a member of the Hungarian branch, has worked closely with us for several years. Her work with co-author András Rónai, focusing on the music of Hungarian artist Bea Palya, is to be published as part of Bloomsbury's 33 1/3 book series (Szemere and Rónai 2021). Szemere and Rónai study the themes of gender as well as nostalgia through an analysis of Palya's album Én leszek a játékszered (2010), where she reinterprets popular songs from the socialist period.

The area of jazz studies is also experiencing growth, in a large part thanks to Ádám Kornél Havas, whose PhD dissertation (2019) and other publications (e.g. Havas and Ser 2017) focus on the Hungarian jazz music scene. His forthcoming article in Popular Music "aims to make the contemporary Hungarian jazz field the focus of a sociological investigation, based on a critical reinterpretation of Bourdieu's relational theory of artistic fields" (Havas 2020). In particular, the article focuses on analysing the dichotomy between free jazz and mainstream jazz, with the aim of uncovering the logic of symbolic distinctions. Through his analysis, Havas demonstrates how this dichotomy is constructed historically, and is embedded into social structures of ethnicity and class. Besides his own publications, Havas has also co-edited a Hungarian-language journal issue on jazz studies (Havas and Zipernovszky 2018), has co-organised the first and second International Jazz Studies Symposia in Budapest, and is currently co-editing a Popular Music and Society special journal issue on jazz and diasporas with Bruce Johnson.

The study of (digital) technology and popular music remains an important area for the branch, with an increasing emphasis on exploring Eastern-European 
perspectives within global music industries. The international conference "Communicating Music Scenes: Networks, Power, Technology" (held at the Institute of Musicology in May 2017 in Budapest and organised by Ádám Ignácz, Tamás Tófalvy, and myself) provided a space for scholars from around the world, including IASPM members, to discuss cases and theories around the relations between people, formal and informal institutions, and technologies in the context of music making. Our forthcoming edited volume (Tófalvy and Barna 2020), which partly draws on work presented at the conference, examines infrastructures and practices of music making and consuming marked by the emergence of digital tools and platforms such as YouTube or Spotify, primarily focusing on the post-Napster era of digitization but also including chapters looking back on the technological precursors to digital culture. Tófalvy's most recent work, furthermore, covers new ground in the field of music and digital technology by addressing the ways in which geographical inequalities are being reproduced through the algorithm design of music streaming services such as Spotify, based on Hungarian examples.

As part of the international comparative research project "Popular Music and the Rise of Populism in Europe" (founded by Volkswagen Stiftung, ref. 94 754; 20192022), Ágnes Patakfalvi-Czirják and myself have been exploring the relationship between populism and popular music in Hungary, compared with case studies from Sweden, Italy, Germany, and Austria. Combining field work with musicological group analysis (with the involvement of Ádám Ignácz) and focus groups, this research is aimed at understanding how popular music affords populist interpretations, contributing to the mainstreaming of populist ideologies in a particular local context.

Gender and popular music is a further area that has received increased attention, partly through the international symposium "Gender and Creativity in Music Worlds". This symposium was organised in relation to the international project MusicaFemina, with Anna Szemere, Tamás Tófalvy and myself as members of the academic committee, and was held in January 2020 in Budapest. The symposium focused on three main areas: gender and the music industries; gender (studies), education and pedagogies; and gender and music in Central and East Europe. My own 4-year research project entitled "Creative Labour in the Hungarian Music Industries" (running between 2018 and 2022 and funded by the Hungarian National Research, Development and Innovation Office; FK-128669) combines a focus on gender and digital technology with a creative labour perspective. Focusing on the work of people active in the Hungarian music industries, I aim to explore the mechanisms through which gender inequalities operate in the field of the music industries, and to theorise the relationship between these mechanisms and the power relations of the broader social structure, as well as mapping the structures of access to, and use of, resources, whether material, infrastructural, emotional or creative.

\section{References}

\section{Bibliography}

Barna, E. 2016. Newsletter - IASPM Hungary. http://www.iaspm.net/archive/newsletters/Hungary_2016.pdf Accessed: 1 May 2020. 
Barna, E. and Á. Ignácz. 2018. Musical and Social Structures: Marxist Interpretations of Popular Music in the 1960s and early 1970s in Hungary and the UK. IASPM Journal 8 (2): 2-17. http://dx.doi.org/10.5429/20793871(2018)v8i2.2en

Barna, E., M. Madár, K. Nagy and M. Szarvas. 2019. Dinamikus hatalom. Kulturális termelés és politika Magyarországon 2010 után. Fordulat 26: 225251.

Barna, E. and T. Tófalvy, Eds. 2017. Made in Hungary: Studies in Popular Music. New York and London: Routledge.

Havas, Á. K. -

2019. Szegény rokonok: A magyar jazzszcéna szerkezete és rétegződése. PhD. Corvinus University Budapest.

2020. The Logic of Distinctions in the Hungarian Jazz Field: A Case Study of Hungarian Jazz. Popular Music (forthcoming).

Havas, Á. and Á. Ser. 2018. "Szegény rokonok" - A budapesti jazzszíntér konstrukciója. Replika 101-102: 147-168.

Havas, Á. and K. Zipernovszky, Eds. 2018. Jazztanumlányok. Replika 101-102: 7209.

Ignácz, Á. -

2020a. Milliók zenéje. Populáris zene és zenetudomány az államszocialista Magyarországon. Budapest: Rózsavölgyi és Társa.

Ed. 2020b. A magyar populáris zene története(i): Források - módszerek perspektívák. Budapest: Rózsavölgyi és Társa (forthcoming).

Szemere, A. and A. Rónai. 2021. I'll Be Your Plaything": The Spirited Reinvention of Femininity in Bea Palya's Cover Album. London, Oxford, New York, New Delhi, and Sydney: Bloomsbury Academic (forthcoming).

Tófalvy, T. and E. Barna, Eds. 2020. Popular Music, Technology, and the Changing Media Ecosystem. From Cassettes to Stream. London: Palgrave Macmillan.

Wagner, S. 2018. Szocialista kereslet, kapitalista kínálat - és fordítva. Hozzáférés a Syrius-dokumentumokhoz (1970-1973). Replika 3-4: 265-293. http://dx.doi.org/10.32564/108-109.12

\section{Discography}

Palya Bea. 2012. Én leszek a játékszered. Sony Music, Hungary. 